\title{
A tanulási folyamat időbeli eloszlásának és eredményességének vizsgálata a
}

\author{
kalkulustanulásban
}

\section{Bevezetés}

Mind a mérnök-, mind a gazdasági képzés matematikaoktatásában a hallgatónak a szaktárgyakban alkalmazható tudást kell szereznie. Nem ritkán az is előfordul, hogy a matematika kurzuson megtanultak csak néhány szemeszterrel később kerülnek felhasználásra. További nehezítő tényező annak felismerése, miként van jelen egy adott ismeret a szaktárgyban, hiszen az sosem egyértelmúen, egy kiszámolandó feladatként jelenik meg, hanem megértve a mérnöki-, gazdasági jellegú problémát, le kell azt fordítani a matematika nyelvére, majd megoldani azt a Kalkulus kurzusokon tanult ismeretek segítségével. Mindebből látszik, hogy milyen fontos a tartós tudás megszerzése ezeken a szakokon is.

A legújabb emlékezetkutatási eredmények ismeretében nem akkor járunk el helyesen, ha tanítási metódusainkat a korábbi tanuláselméleti modellekre támaszkodva próbáljuk kialakítani. Sokáig azt gondolták, a hallgató feje egy hordó, amibe a tanár tölti a tudást és bár az itt-ott kifolyik, de tovább töltve mérsékelhetjük a veszteségeket. Később a kutatók a rendszerezést is beépítették a modelljeikbe, így már egy sokfiókos szekrényre helyesebb gondolnunk, amelyben a megfelelő helyeken elraktározódnak a szükség szerint előhívható információk (Köhler 1947, Weiner 1966). Itt a minél többszöri bevitel az, ami segít abban, hogy minden a megfelelő fiókba kerüljön, hiszen a raktározási hibák felejtés formájában öltenek testet.

A felejtés nemlineáris voltáról először Hermann Ebbinghaus 1885-ös könyvében számol be, amiben a felejtésgörbe logaritmikus voltát fogalmazza meg, ekkor még olyan peremfeltétel mellett, hogy az előhívás nem változik a késleltetéssel (Ebbinghaus, 1885). A 20. század végén, a 21. század elején végzett kísérletek (Moar 1978, Koriat 2005) bizonyították be, hogy ez a feltevés hibás.

Sokáig tartotta magát az az elképzelés is, hogy a könnyen bevitt (megtanult) anyag a későbbiekben könnyen előhívható, ezért célszerű a bevitelt különböző módszerekkel (gondolatfelhők, kiemelés, ábrázolás...) megkönnyíteni. Mára azt is tudjuk, van a tanulási folyamatnak egy kívánatos nehézségi szintje (Kornell, 2010).

A felejtés mértékének tekintetében nagyon fontos, hogy a megtanulást követően mikor történik az előhívás. Spitzer nagy elemszámú ( $\mathrm{N}=3605)$ mintán elvégzett kísérletéből (Spitzer, 1939) vált ismertté, hogy minél hamarabb, annál tartósabb lesz a tudás. Pyc és Rawson (Pyc, 2009), bebizonyították, hogy fontos az előhívási időközök helyes megválasztása, valamint a tesztelés többszöri alkalmazása. Alan Baddeley és munkatársai (Baddeley, 2019) kiemelték a tesztelés széles körű szerepét: nem elegendő egyetlen témára rákérdezni, a tartósabb tudás teljesebb, részletesebb tesztelést igényel. Emellett növeli a tanulás hatékonyságát a tesztet követő megerősítés is, azaz ha a kitöltő megtudja, hogy az általa adott válaszok helyesek voltak-e (Wheeler, 2003). A transzferhatás ugyancsak abban erősít meg bennünket, hogy a tesztelés eredményes módszer (Butler, 2010) a mérnöki- és gazdasági matematika képzésben. A BME Kognitív Tudományi Tanszékén Racsmány Mihály és munkatársai régóta foglalkoznak a teszthatás kutatásával (Keresztes, 2019; Racsmány, 2015). Ők is segítették munkánkat, hogy egy a hétköznapi gyakorlatba jól átvihető metódust alakíthassunk ki.

\section{Matematikaoktatás a BME Gépészmérnöki Karán}

Több éve igyekszünk a BME Gépészmérnöki Karának mechatronikus és energetikus hallgatói számára a matematikát úgy oktatni, hogy a teszthatás előbb felsorolt előnyeivel élhessünk. A felsőoktatás tanítási struktúrája simul leginkább a régi modellekhez, hiszen a rendelkezésre álló időben előadások és gyakorlatok alatt is az új anyag átadására kerül sor. Egy-egy szemeszterben két-három zárthelyi 
dolgozat sikeres teljesítésével jut el a hallgató a vizsgához. Nem ritka, hogy mindez a diákság számára három huzamosabb ideig tartó, tömbösített tanulást jelent a számonkérést megelőző nappalokon és éjszakákon.

Mivel az ilyen tanulás a megszerzett jegy szempontjából nem eredménytelenebb a tartósabb tudást adó módozatoknál, a hallgatók nem motiváltak abban, hogy változtassanak tanulási szokásaikon. Sőt azt tapasztaljuk, hogy a tömbösített tanulás mostanra a közoktatásban is teret nyert, így a diákok úgy jelennek meg az egyetemeken, hogy a tanulás számukra egy közvetlen megmérettetés előtti tevékenység.

Közel tíz éve kezdtünk el azon munkálkodni, miként tudnánk ezt a tendenciát megtörni, a hallgatókat a folytonos tanulásra ösztönözni. Kiegészítettük ezt azzal is, hogy a kalkulus gyakorlatok végén teszteléssel segítjük a tanulást. Az órák utolsó perceiben a diákok oldanak meg egy-két feladatot, előhívva és ezzel erősítve a frissen tanultakat. Ez azonban önmagában nem lenne elegendő, hiszen a mérnök- és gazdasági képzésben egyaránt olyan nagy az elsajátítandó anyag mennyisége, hogy a többszöri tesztelést az otthoni tanulásba is be kell építenünk.

\section{Matematikaoktatás felépítése - reguláris tárgyak}

A Gépészmérnöki Karon a matematikaoktatás célja, hogy ezeken a mérnöki területeken előforduló és gyakran használt matematikai fogalmakkal megismertesse a hallgatókat. Ezért a matematika szigorlati tantárgyblokk az egy- és többváltozós analízis, a lineáris algebra, a vektoranalízis és a differenciálegyenletek tanítására épül. A tanított matematikai ismeretek számos, később tanult szaktárgy keretein belül előkerülnek, azonban előfordul az is, hogy a hallgatóknak abban a félévben kell alkalmazniuk a megszerzett tudást, amikor azt matematikából tanulják. Ezért elengedhetetlen a félévközi tanulás és gyakorlás. A hallgatók az első három szemeszterben az alábbi bontásban ismerkednek meg a kalkulus elemeivel.

- Matematika G1 (BMETE94BG01) címú tantárgyat a hallgatók az első félévben hallgatják. A tárgy taglalja a komplex számok algebráját és az egyváltozós analízis témaköreit (differenciál- és integrálszámítás), illetve analitikus geometriával előkészíti a Matematika G2 tárgy számára a vektoralgebra egyes részeit. A tantárgy a középszintű érettségi matematika tananyagának ismeretét feltételezi, az emelt szintű érettségivel érkezők számára a tárgy anyagának jelentős része ismert lehet. E kurzus anyagát szinte az összes műszaki szaktárgy felhasználja valamilyen mértékben.

- Matematika G2 (BMETE94BG02) elnevezésű tantárgyat a második félévben oktatjuk. A szemeszter első felében mind az előadások, mind a gyakorlatok a függvénysorozatok és a lineáris algebra témaköreivel, míg a második felében többváltozós analízissel foglalkoznak. A tapasztalatok azt mutatják, hogy ezek a témakörök már nem fordulnak elő a középiskolás tananyagban, így minden hallgató itt hall róluk először. Az itt tanultak ugyancsak nélkülözhetetlenek a szaktárgyak zömében.

- Matematika G3 (BMETE94BG03) címú tantárgy az utolsó kötelező kurzus matematikából az alapképzésben. A második féléves tárgyhoz hasonlóan ez is két nagyobb témakörből áll: első felében a vektoranalízis, második felében a differenciálegyenletek témaköreivel foglalkozik. A szaktárgyak ráépülését tekintve ezen félévben megszerzett matematika tudásra van a legtöbbször szüksége egy mérnökhallgatónak.

\section{Tesztelésen alapuló oktatási módszer}

Az általunk kidolgozott módszer alkalmazásával az a célunk, hogy úgy gyarapítsuk a hallgatók tudását, hogy képesek legyenek a megszerzett ismereteket a szaktárgyakban alkalmazni. Át szeretnénk adni az oktatással a megismerés, a megértés örömét. Mindezt úgy, hogy nyomon követhessük hallgatóink aktivitását, tanulási hatékonyságát, tanulásmintázataikat, és megfelelően kezeljük a különböző matematikatudással érkező hallgatók kompetenciáit. A kialakított módszertan legfontosabb pillérei: 
- teszthatáson alapuló oktatási módszer alkalmazása,

- a tematika bővítése gyakorlati alkalmazásokkal,

- hallgatóközpontú motivációs rendszer kidolgozása,

- felzárkóztatás, korrepetálás és tehetséggondozás biztosítása,

- online oktatási forma bevezetése a reguláris és tehetséggondozó tárgyak esetén egyaránt

Az EduBase Online oktatási platform alkalmazásával sikerült azt elérnünk, hogy diákjaink a folytonos profilozhatóság mellett a tesztelésre ne a számonkérés egy módjaként, hanem a tanulási folyamat részeként tekintsenek, és a mindennapokban önállóan is alkalmazzák azt.

\section{EduBase online oktatási platform}

Az online oktatást az EduBase (www.edubase.net) felhőalapú oktatási platform egyedi tesztelő és vizsgáztató rendszerével valósítottuk meg. Ezen integrált oktatási felület eszköz- és platformfüggetlenségével biztosítja széleskörű használhatóságát.

A felület megjelenése modern, kezelése rendkívül egyszerű és kényelmes, használata nem igényel külön oktatást. Webes megoldás lévén nincs különleges hardverigény, nem kell semmit telepíteni, a tananyagok és a tesztek számítógépről, laptopról és akár tabletről is bármikor elérhetőek.

Az EduBase-en történő egyszerű regisztráció után az oktatók létrehozhatják digitális osztálytermeiket, melyekben rendkívül egyszerúen megoszthatnak oktatási segédanyagokat (videókat, dokumentumokat, PPT előadásokat és egyéb fájlokat), kiírhatnak beadandókat, és készíthetnek online teszteket, házi feladatokat vagy akár témazáró dolgozatokat/vizsgákat is. Az EduBase remek együttműködési felületet is biztosít az oktatóknak, hiszen a feltöltött anyagokat, kérdéseket más oktatókkal is megoszthatják, felhasználva azokat saját osztályaikban, ezzel tovább növelve az EduBase köré épült tanári közösség hatékonyságát.

A tananyagok mellett természetesen lehetőség van a tudás visszamérésére online teszteken keresztül. Sokoldalú, változatos tesztjeinkbe beépíthetőek feleletválasztós, igaz-hamis, numerikus, szöveges vagy akár komplex matematikai kifejezéses kérdéstípusok is. Igény szerint a tesztek tartalmazhatnak segítő jellegű, rávezető kérdéseket illetve kapcsolódó képeket, videókat is. Egy elvégzett teszt eredménye azonnal láthatóvá válik a kitöltők és a felügyelők (vagy az arra jogosultak) számára. Láthatóak az egyéni teljesítmények, de választható többféle összesítés és statisztikai megjelenítés is.

Az EduBase tesztelörendszerének különlegessége, hogy a matematikai feladatok paraméterezhetők, ami azt jelenti, hogy akár minden diáknak ugyanaz a feladat különböző számokkal fog megjelenni, de nem lesz egyik sem nehezebb a másiknál. Így sokkal többet lehet egy feladattal gyakorolni illetve dolgozat esetén a társról nem lehet lesni sem.

\section{Hallgatói minta}

Jelen munkánkban azt szeretnénk bemutatni, hogy az új módszer alkalmazásával miként alakult a tesztelés időbeli eloszlása, mennyivel volt eredményesebb az osztott tanulás a tömbösítettnél.

1. táblázat. A vizsgálatba bevont hallgatók felvételi pontszámának alakulása

\begin{tabular}{|l|l|l|l|}
\hline \multicolumn{1}{|c|}{ Szak } & Férfiak & \multicolumn{1}{c|}{ Nők } & Összesen \\
\hline Mechatronikai mérnök szak & 72 & 10 & 82 \\
\hline Energetikai mérnök szak & 38 & 4 & 42 \\
\hline Összesen & $\mathbf{1 1 0}$ & $\mathbf{1 4}$ & $\mathbf{1 2 4}$ \\
\hline
\end{tabular}


A kutatásba a BME Gépészmérnöki Karának hallgatói közül a 2018/2019. akadémiai évben, energetikai és mechatronikai mérnök szakra jelentkezett hallgatóit vontuk be. Összesen 124 gólya kezdte meg ebben a tanévben az egyetemi tanulmányait. A csoport jelentős része 18 és 22 év közötti férfi $(88,7 \%)$, s mindösszesen a 11,3\% volt ugyanezen korosztályból származó női hallgató. A vizsgálatba bevont hallgatók felvételi pontszámának alakulását az 1. ábra szemlélteti. Korábbi évekhez hasonlóan 2018-ban is GPK mechatronikai mérnök képzésén volt a legmagasabb felvételi ponthatár a mérnök szakokat tekintve (Mechatronikai mérnöki szak: 451 pont; Energetikai mérnöki szak: 389 pont (Oktatási Hivatal, 2018).

1. ábra. A vizsgálatba bevont hallgatók felvételi pontszámának alakulása

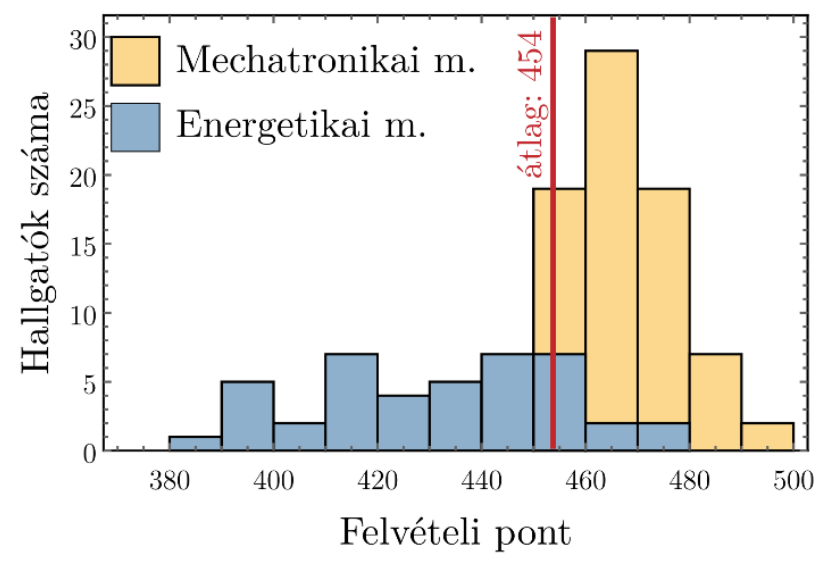

\section{Online oktatás megvalósítása}

Az online oktatás a következő, a diákok által az első szemeszterben már megismert, menetrend szerint zajlott. Minden gyakorlatvezető létrehozta a saját digitális osztálytermét, amelyben kiadta a házi feladatokat, kommunikált a hallgatókkal, nyomon tudta követni a tankörébe tartozók haladását. A digitális osztálytermen keresztül minden héten kírásra kerültek a házi feladatok. Ezek egy hétig (csütörtök reggel 8 órától szerda éjfélig) voltak elérhetők, a diákok bármikor megnyithatták és kitölthették a tesztsort ezen időszakban, azonban a megadott határidő előtt azokat elektronikusan "be kellett adni" (2. ábra).

2. ábra. Az EduBase rendszerében létrehozott osztályterem

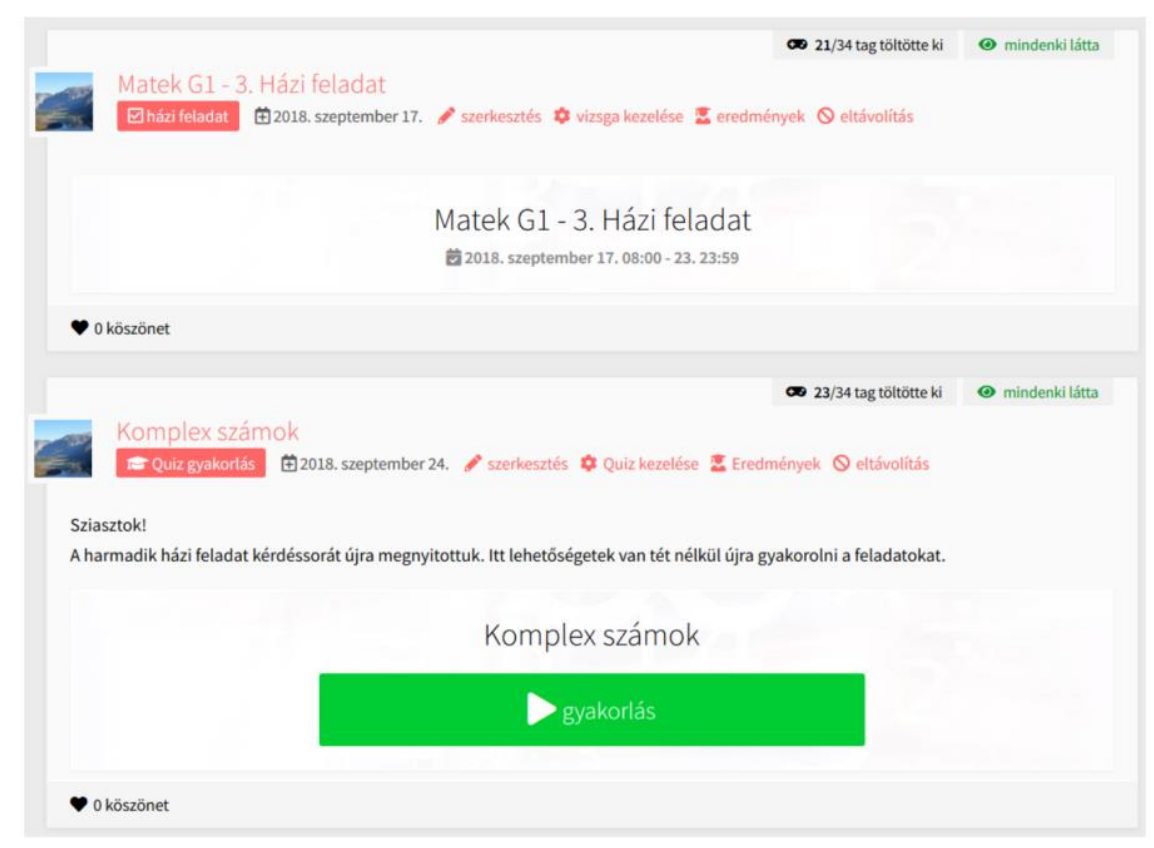


A házi feladatok tematikája az adott heti gyakorlat témaköreihez igazodott. A feladatok egyrészt ellenőrizték a gyakorlaton megszerzett tudást, másrészt segítségükkel lehetőség volt újabb ismeretek elsajátítására is, amelyek aztán ismét tesztelésre kerültek. A kiadott feladatok között többször szerepelt paraméteres feladat, amely minden belépéskor újabb, a korábbitól eltérő paraméterhalmazt generált. Így azonos nehézségű, de nem pontosan ugyanolyan feladaton lehetett végezni a tesztelést.

Az EduBase rendszerében folyó munka a teszthatásos tanulás produktív kivitelezési módja. A rendszer a beadás után automatikusan kiértékeli a tesztsorokat, ezzel a hallgatók azonnali visszajelzést kapnak. A beadási határidő után ezen tesztsorok feladatait újból megnyitjuk a hallgatók számára (2. ábra). Ezúttal nem házi feladatként, hanem úgynevezett gyakorló üzemmódban elérhetők. Gyakorló üzemmódban a felhasználó kérhet segítséget a feladat megoldása során, valamint az értékelés után lehetősége van a részletes megoldásmenet megtekintésére is. Az online rendszernek köszönhetően a hallgatók minden tevékenysége digitálisan naplózódik. Így a hallgatók eredményein túl a rendelkezésünkre áll minden olyan információ is, hogy mikor, mennyi időt töltöttek gyakorlással, teszteléssel, melyik feladattípust, milyen arányban tudták megoldani stb. Ezeknek a segítségével váltak a tanulási folyamatok és tanulási szokások nyomon követhetővé.

\section{Oktatási módszerünk eredményességének elemzése}

A félévközi teljesítmény értékelésére két zárthelyi dolgozat szolgált a félév során. Az első zárthelyi dolgozatot $(1 . \mathrm{ZH})$ a hetedik, a második zárthelyi dolgozatot $(2 . \mathrm{ZH})$ a tizenharmadik oktatási héten írták a hallgatók. A tárgy vizsgával zárul, így a második zárthelyi dolgozat utáni témakörök a vizsgán kerülnek kikérdezésre. A hallgatók félévközi zárthelyi dolgozatainak az eredményeit az alábbi hisztogramon szemlélteti (3. ábra). Ezen szürkével jelöltük a sikertelen teljesítést (sikeres teljesítéshez legalább $40 \%$ szükséges), illetve pirossal a $65 \%$ feletti eredményeket. A $65 \%$ felett teljesítő hallgató esetén tekintjük úgy, hogy megfelelően mély tudást szerzett ahhoz, hogy a későbbi tanulmányai során sikeresen alkalmazza a tanultakat. Így a hallgatók eredményeinek további elemzésekor is ezt a "választóvonalat" használjuk.

3. ábra. A vizsgálatba bevont hallgatók zárthelyi eredményének eloszlása
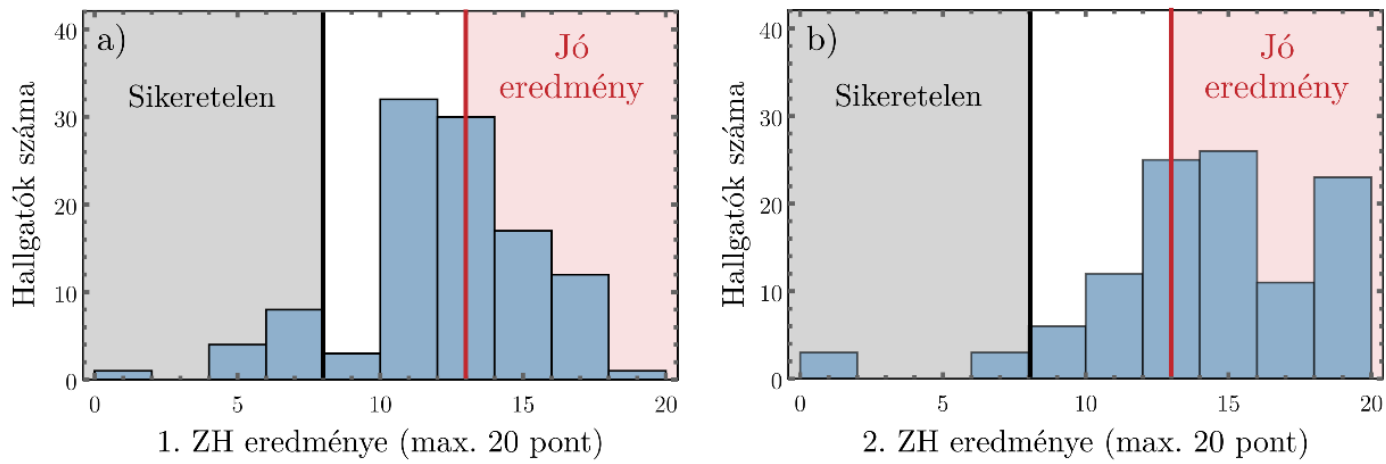

\section{Az online tanulási idő mintázata}

Az online tanulási szokások elemzéséhez először az EduBase rendszerében kiadott házi feladatok adatait vizsgáltuk. Az összes online tanulással töltött órákat és az online aktív hallgatók számát napokra lebontva a 4. ábra szemlélteti. A bal oldali tanulási térkép (4/a. ábra) az összes tanulással töltött órákat, míg a 4/b. ábrán lévő tanulási térkép az online aktív hallgatók számát ábrázolja napi bontásban, a hét napjai szerint ciklikusan rendezve. A tanulási térképeken jól látható, hogy az aktív gyakorlással töltött órák a hétvégén és szerdánként jelentősen többek, mint a többi hétköznapokon. Ennek oka egyrészt, hogy a kiadott házi feladatok beadási határideje szerda éjfél volt, másrészt a hallgatók hétköznapi oktatási terhelése nagyobb az egyetemi kontaktórák miatt, ezért az online gyakorlásra szánt idejük kevesebb. A hallgatói létszámot tekintve azt mondhatjuk, hogy egy hét alatt majdnem a teljes hallgatói 
mintát sikerült elérni az online felület segítségével, így a heti két előadás és heti egy gyakorlat mellett legalább heti egyszer foglalkoztak a hallgatók az online kiadott házi feladatokkal is.

\section{4. ábra. A vizsgálatba bevont hallgatók napi aktivitásainak szemléltetése}

a) Napi online tanulással töltött összes idő

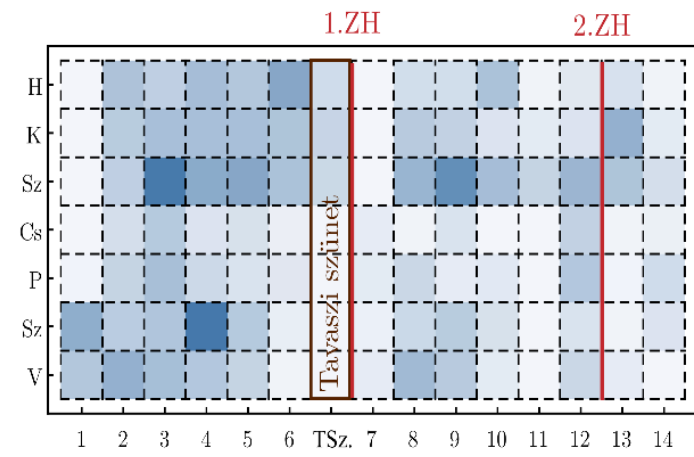

Hét

b) Napi online tanulással foglalkozó összes hallgató

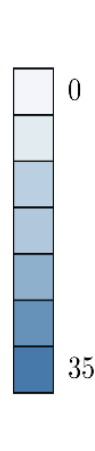

35

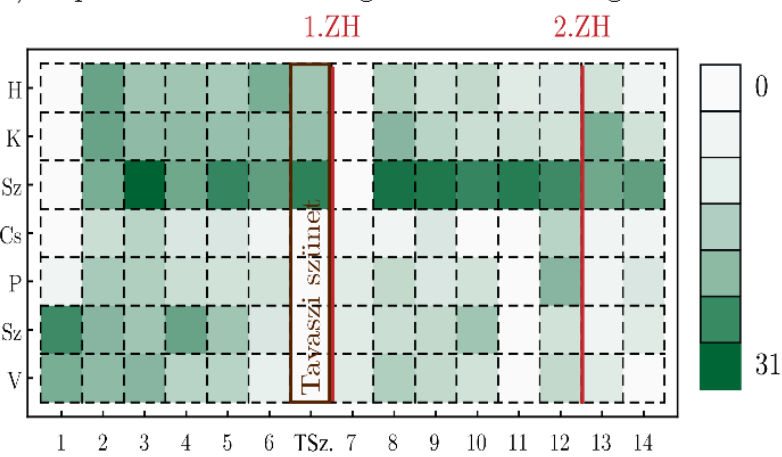

Hét

Az 5. ábra heti bontásban mutatja a gyakorlással töltött órák számát (kék vonal) és az elért eredmények átlagát (zöld vonal). Jól látható, hogy a szemeszter elején több ideje van a hallgatóknak gyakorolni, az új anyaggal (lineáris leképezések) sokat foglalkoztak, újszerűsége, nehézsége ellenére jól teljesítették azt. A 6. héten a nagyobb terhelés okán sokkal kisebb a gyakorlásra szánt idő, majd az új témakört (függvénysorok) már kevesebbet gyakorolják, ami látható az eredményeken is. A 10. hét környékén bár alacsony a gyakorlásra fordított idő, a téma könnyebbsége (többváltozós függvények differenciálszámítása) miatt az eredményesség nem csökken. A teszthatás eredményességét is mutatja, hogy a diákok jól emlékeznek az első félévben megtanultakra (Berezvai, 2019a; Berezvai 2019b).

Az egyváltozós analízis témaköreinek eredményes elsajátítása megjelenik ott is, hogy a viszonylag kevés gyakorlási idő ellenére sem olyan rosszak a többváltozós függvények integrálszámításában elért eredmények.

\section{5. ábra. Az egyes gyakorló feladatsorokkal töltött órák és az átlagos eredményesség változása}

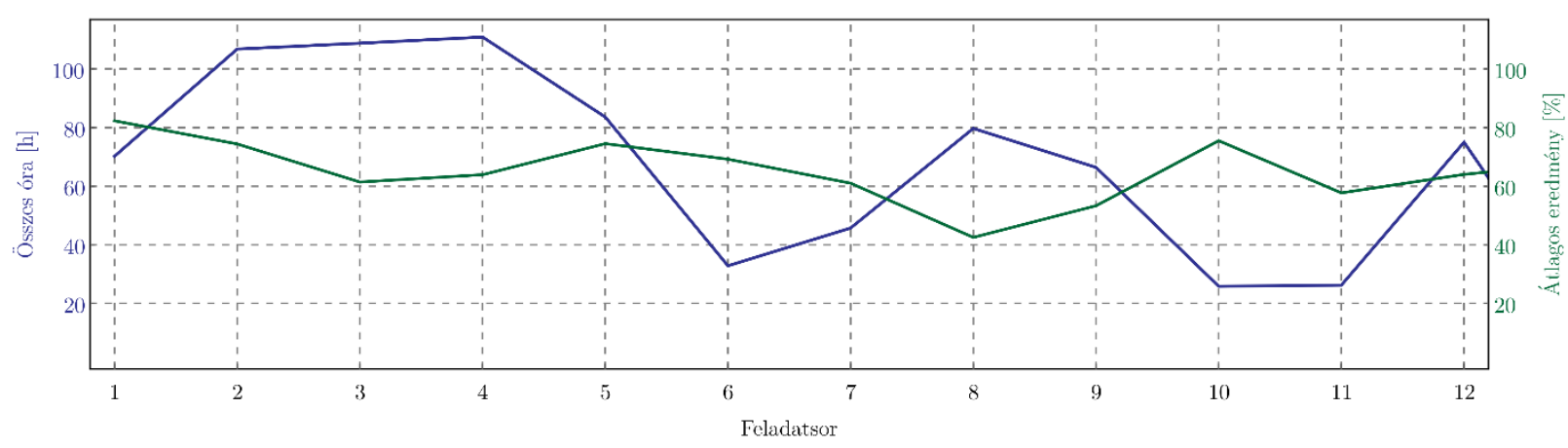

\section{Kampányjellegű és folyamatos tanulás}

Az online teszteléssel töltött órák mellett kíváncsiak voltunk arra is, hogy a hallgatók mennyire élnek a gyakorlás lehetőségével a házi feladatok beadásán túl. Így a tanulási mintázatok vizsgálatában a házi feladatok kitöltéséből nyert adatokat kiegészítettük az újra megnyitott tesztek gyakorlási idejével is. Hipotézisünkkel összhangban, azon hallgatók, akik főleg a két nagy számonkérés előtt vesznek igénybe plusz online gyakorlási lehetőséget, kampányjellegú tanulást folytatnak, míg azok, akik folyamatosan gyakorolnak a házi feladatokkal és az online gyakorlósorokkal, alaposabb tudásra tehetnek szert, még ha összességében esetleg kevesebb időt is töltenek az EduBase rendszerében, tehát kevesebb időt fordítanak tanulásra. A folyamatos tesztelés eredményességének bemutatására ezeket a mintázatokat szeretnénk elkülöníteni. Ehhez egy új arányszámot definiáltunk $(\kappa)$, amely 1 és 0 közötti értékeket 
vehet fel és a nem kampányjellegú tanulás jellemzésére szolgál - innen az elnevezés, non-campaign ratio (Berezvai et al., 2019). A bevezetett definíció alapján

$$
\kappa=1-\frac{T_{-1}}{T}
$$

ahol $T_{-1}$ jelöli az összes tanulással töltött órák számát az adott számonkérésig (első- vagy második zárthelyi dolgozat), $T$ pedig az összes tanulással töltött órát az adott számonkérés előtti hétig. Ebben az esetben az összes tanulással töltött időbe a házi feladattal töltött idő és a plusz gyakorlással töltött idő is beleszámít. A $\kappa$ arányszám tehát azon hallgatók esetén lesz 1-hez közeli érték, akik folyamatos teszteléssel tanultak a félév során, és 0 -hoz közeli azon hallgatók esetén, akik a kampányjellegű tanulást választva, csak a számonkérés előtti napokban használták az online rendszert.

A hallgatók eredményeit számonkérésenként ábrázoltuk (6. ábra). A sárga hisztogramon azoknak a hallgatóknak az eredményeit szemléltetjük, akiknek a zárthelyi dolgozatuk eredménye $65 \%$ feletti, míg a kék hisztogramhoz a $65 \%$ alatti eredmények tartoznak. Az eredmények értékeléséhez csak a sikeres, legalább 40\%-os dolgozatok eredményeit használtuk. A kampányjellegú és a folyamatos tanulás elkülönítéséhez az ábrák alapján a $k=0.6$ értéket határoztuk meg. Amikor az arányszám $60 \%$ alatti, a tanulási folyamatot kampányjellegúnek tekintjük, amennyiben ezen érték feletti, folyamatos tanulásként értelmezzük. Ilyen értékválasztás mellett látható, hogy a jobban teljesítő hallgatók ( 6 . ábra, sárga hisztogramok) tanulási mintázata főként a folyamatos tanulással jellemezhető.

\section{6. ábra. A félévközi teljesítményértékelések ábrázolása a tanulási mintázatok szerint}
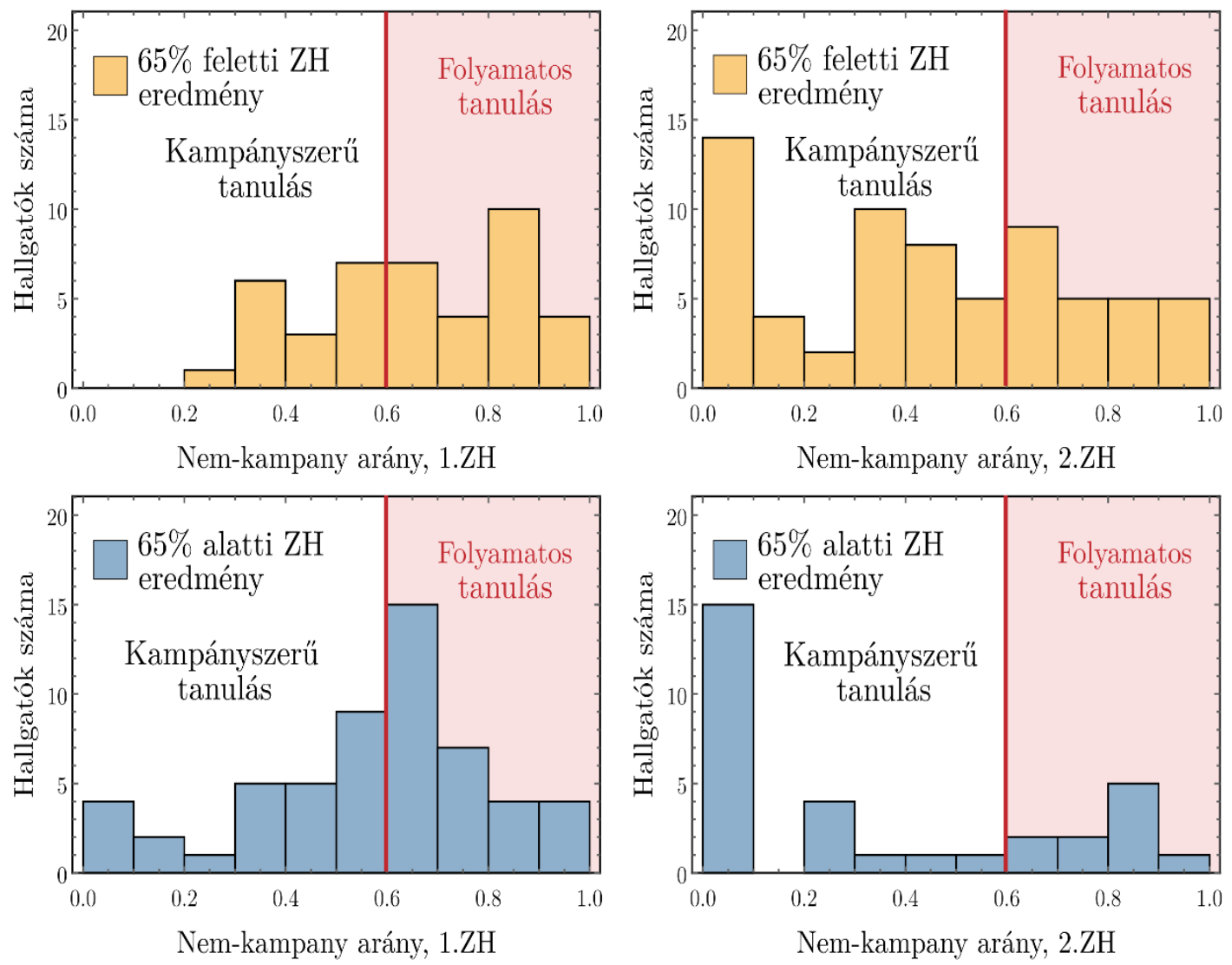

\section{Tanulási hatékonyság}

Vizsgáljuk meg, miként alakul a tanulási hatékonyság a folyamatos és a kampányszerű tanulást folytató hallgatók esetén! Ennek elemzéséhez ismételten a heti rendszerességgel kiadott házi feladatok tesztjeinek adatait és eredményeit használjuk fel. Olyan mérőszámra van szükség, ami az online 
rendszerben töltött idő mellett az elért eredményeket is figyelembe veszi. Ezért ennek jellemzésére az alábbi mérőszámot vezettük be (Berezvai et al., 2019):

$$
\eta=\frac{P_{\partial ̈ s z z}}{T_{\ddot{o ̈ s z}}}
$$

ahol $P_{o s s z}$ az összes beadott online házi feladat pontszáma, $T_{\text {ossz }}$ az összes idő, amit az EduBase rendszerében a házi feladatok megoldásával töltött a hallgató. Így tehát a tanulási hatékonyságot nagynak tekintjük, ha a diák jó eredménnyel végezte a teszteket, és ehhez viszonylag kevés időre volt szüksége. A hatékonyságot ismét külön vizsgáltuk a két félévközi zárthelyi dolgozat esetén, azok eredményeit a $65 \%$ alatti és feletti teljesités szerint bontva. A hallgatók tanulási hatékonyságát a tanulással töltött órák függvényében a 7. ábra szemlélteti. Az általunk definiált hatásfok fordítottan arányos a tanulással töltött összes idővel, így a hallgatókhoz rendelt hatásfokok hiperbolákkal is jellemezhetők. Az átlagos teljesítményhez tartozó hiperbolák és az eredmények $25 \%$-hoz és $75 \%$-hoz tartozó percentiliseit ábrázolva láthatjuk, hogy azok a tanulók, akik a zárthelyin jobban teljesítettek (7. ábra piros görbéi és jelölői), nagyobb tanulási hatékonysággal jellemezhetők.

\section{7. ábra. A tanulási hatásfokok ábrázolása az összes online tanulással töltött idő függvényében}
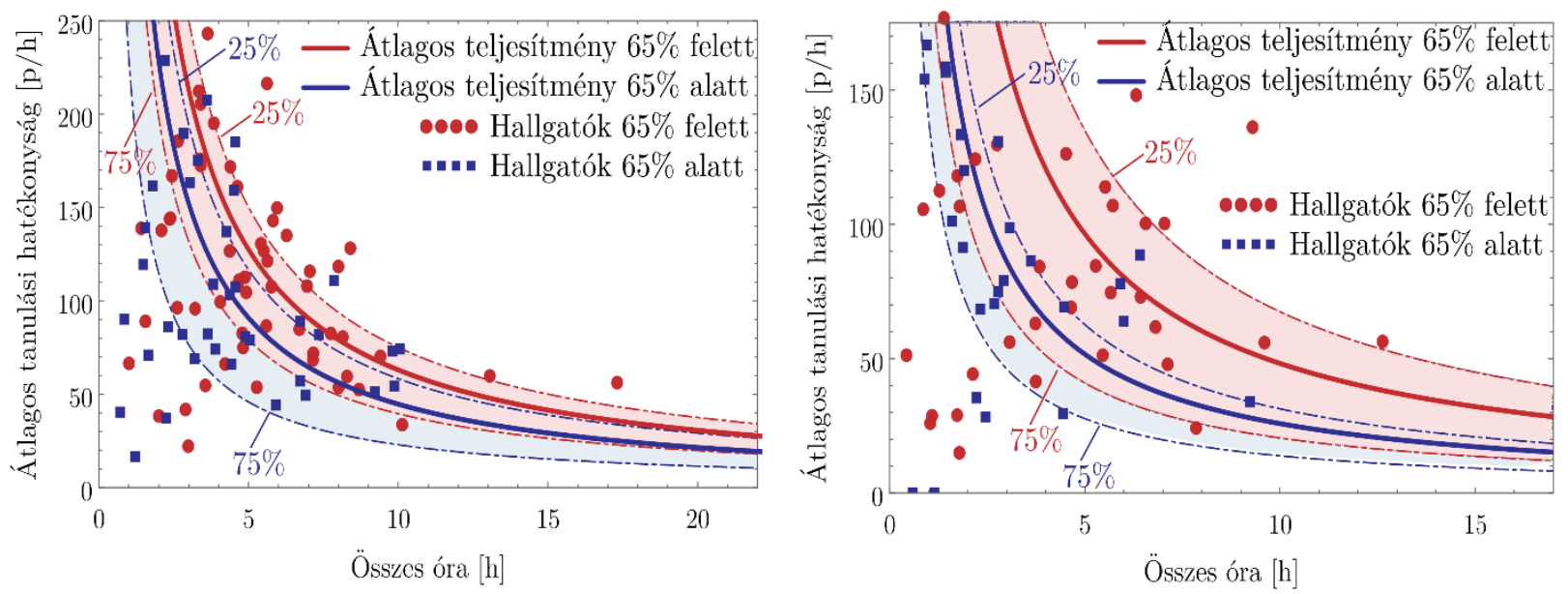

A hallgatói teljesítményeket radardiagrammon vizualizáltuk. Minden hallgatóhoz két hatszög szerkeszthető: az elsőtől a hatodik hétig, azaz az első zárthelyi dolgozatot megelőző házi feladatok eredményeit a hatszög középpontját a csúcsokkal összekötő szakaszokon feltüntetve és ugyanezt a hetediktől a tizenkettedik hétig elért eredményekkel megvalósítva (8. ábra szürke hatszögei). Minél nagyobb területû egy hatszög, annál jobb az elért eredmény, ami tehát egy területtel korreláló mennyiség, míg minél szabályosabb a hexagon, annál egyenletesebb a teljesítmény, azaz ez utóbbi egy kerülettel kapcsolatban álló jellemzője a tanulási folyamatnak. Az ábrán látható kék és piros hatszög a zárthelyiken $65 \%$ felett, illetve alatt teljesített hallgatók átlagából adódó hexagonok.

A sokszögek megrajzolásán kívül még egy, a hatszögre jellemző paramétert meghatároztunk, a terület/kerület $(A / P)$ arányt. $A z$ hatszög terület/kerület arányának elméleti határa 0,433 . $A$ kiegyensúlyozottabb, jó tanulási teljesítmény esetén tehát az $A / P$ arány ehhez közeli kell, hogy legyen. A 8. ábra hisztogramjai ezen $A / P$ arány eloszlását szemléltetik a két zárthelyi dolgozat esetén. $A$ sárgával jelölt hisztogramok azon diákok eredményeit mutatják, akiknél a zárthelyi dolgozat eredménye jobb, azaz $65 \%$ feletti, míg a kék hisztogramok a $65 \%$ alatti eredményekhez tartoznak. $A$ grafikon alapján látható, hogy a jobb zárthelyi eredménnyel bíró hallgatókhoz tartozó $A / P$ arány magasabb, azaz közelebbi értéket vesz fel az elméleti maximumhoz. A terület/kerület arány jelentős csökkenése a hallgatók aktivitásbeli csökkenésének köszönhető. Látható az is, a második zárthelyi dolgozathoz tartozó hatszögek lényegesen kisebbek az elsőnél, amit a tananyag nehézsége mellett a leterheltség okozta kevesebb tanulás is magyaráz. 
8. ábra. Online teljesítmény elemzésének radardiagrammos ábrázolása
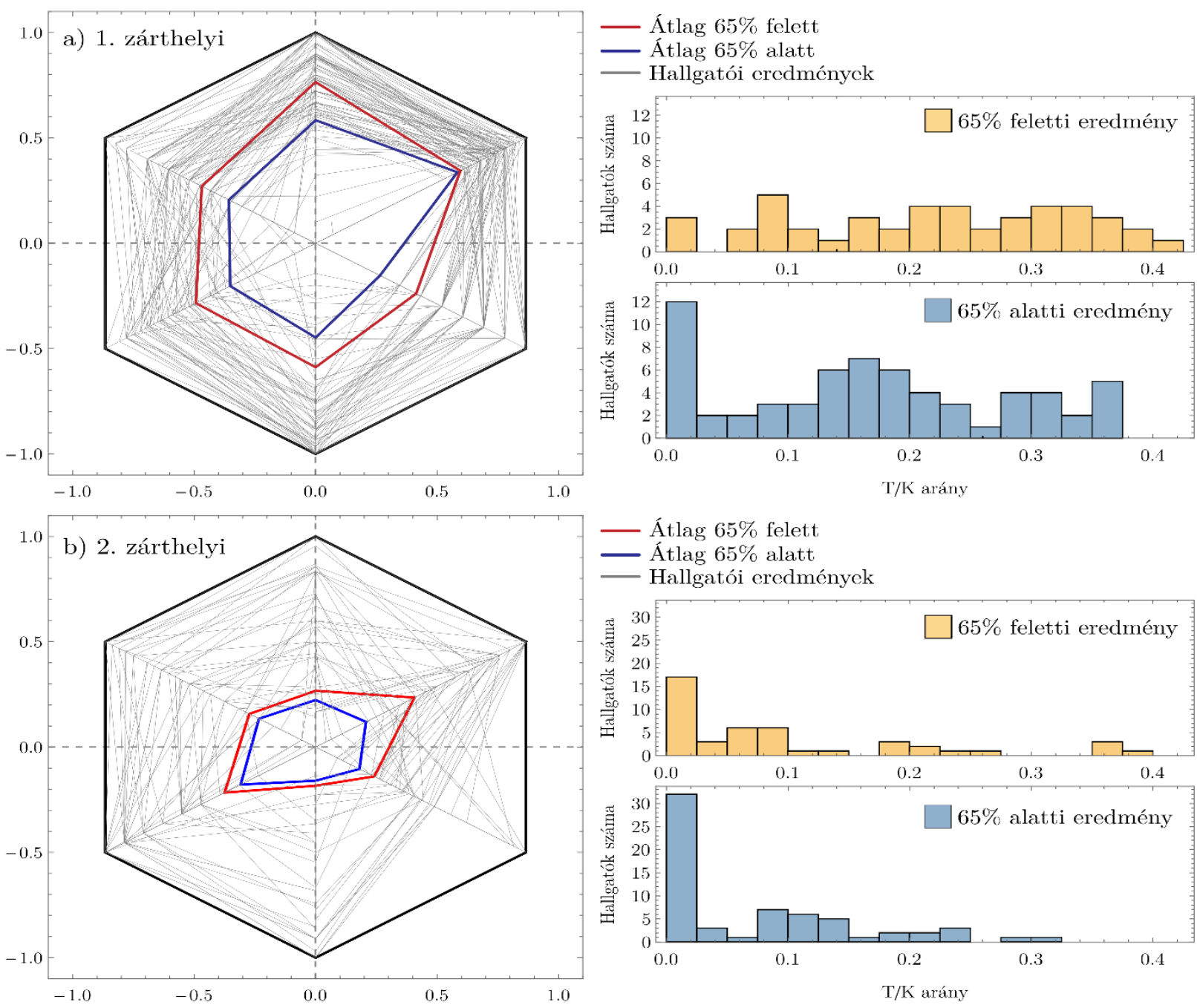

A későbbiekben szeretnénk ezen hallgatói csoport Matematika G3 tárgybeli tanulási mintázatát is elemezni és a Matematika G1 tárgyban kapott eredményekkel összevetni. Megnézzük, miként alakultak egyes diákok tanulási mintázatai, tapasztalunk-e fejlődést a teljesített egyetemi szemeszterek számának függvényében.

\section{Köszönetnyilvánítás}

A Szerzők ezúton szeretnének köszönetet mondani az EduBase Online Kft. munkatársainak az Online Oktatási Platform létrehozásáért, használatának biztosításáért és a kiértékeléshez szükséges adatok rendelkezésre bocsátásáért.

\section{Felhasznál szakirodalom}

- Baddeley, A. - Atkinson, A. - Kemp, S. - Allen, B. (2019): The problem of detecting long-term forgetting: Evidence from the Crimes Test and the Four Doors Test. Cortex, 110, 69-79.

- Berezvai, Sz. - Pálya, Zs. - Hives, Á. - Horváth, D. - Szilágyi, B. (2019a): Innovative monitoring of study time and performance and its efficiency in first-semester calculus course for engineers. In: Nagy, B.V. - Murphy, M. - Jarvinen, HM. - Kálmán, A. (szerk.): Varietas delectat... Complexity is the new normality, Budapest, BME, 1395-1404. 
- Berezvai, Sz. - Pálya, Zs. - Hives, Á. - Horváth, D. - Szilágyi, B. (2019b): Hallgatói tanulási folyamat online monitorozása. In: Tóth, P. - Benedek, A. - Mike, G. - Duchon, J. (Szerk.): Fejlődés és partnerség a felsőoktatásban határok nélkül. Budapest: Budapesti Múszaki és Gazdaságtudományi Egyetem, Műszaki Pedagógia Tanszék, 532-541.

- Butler, A. C. (2010): Repeated Testing Produces Superior Transfer of Learning Relative to Repeated Studying. Journal of Experimental Psychology, 36, 5, 1118-1133.

- Ebbinghaus, H. (1885): Über das Gedächtnis - Untersuchungen zur experimentellen Psychologie. Leipzig: Duncker \& Humblot

- Keresztes, A. - Kaiser, D. - Kovács, Gy. - Racsmány, M. (2014): Testing promotes long-term learning via stabilizing activation patterns in a large network of brain areas. Celebral Cortex, 24, 11, 3025-3035.

- Köhler, W. (1947): Gestalt psychology; an introduction to new concepts in modern psychology. New York: Liveright.

- Koriat, A. - Bjork, R.A. (2005): Illusions of Competence in Monitoring One's Knowledge During Study. Journal of Experimental Psychology: Learning, Memory, and Cognition, 31, 2, 187-194.

- Kornell, N. - Castel, A. - Eich, T. S. - Bjork, R. A. (2010): Spacing as the friend of both memory and induction in young and older adults. Psychology and Aging, 25, 2, 498-503.

- Moar, I. (1978). Mental triangulation and the nature of internal representations of space. PhD Thesis. University of Cambridge, Cambridge, United Kingdom.

- Pyc, M. - Rawson, A. K. (2009): Testing the retrieval effort hypothesis: Does greater difficulty correctly recalling information lead to higher levels of memory? Journal of Memory and Language, 60, 4, 437-447.

- Racsmány, M. - Keresztes, A. (2015): Initial retrieval shields against retrieval-induced forgetting. Frontiers in Psychology, 6, Article 657.

- Spitzer, H. F. (1939): Studies in retention. Journal of Educational Psychology, 30, 9, 641-656.

- Weiner, B. (1966). Role of success and failure in the learning of easy and complex tasks. Journal of Personality and Social Psychology, 3, 3, 339-344.

- Wheeler, M. A. - Ewers, M. -Buonanno, J. F. (2003): Different rates of forgetting following study versus test trials. Memory, 11, 6, 571-580. 